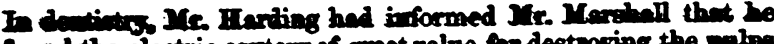
end the elotric antery of gront nolve for destnoging the pelpes

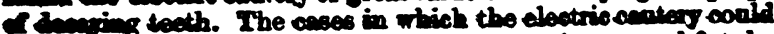

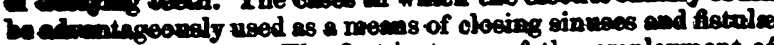
weis ren nunerons. The first inctarce of the empleyment of th cloctric cantery, whether in England or out of it, was a case

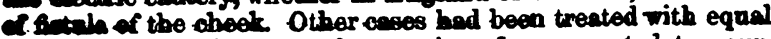
wowes In eve instance, the remains of an encysted temour, the interior of which secreted bair and sebecoous matter, wos - Motinally dostroyed, after no less than seven provious unsuccosefel attempts by extirpation, laying open the oyst, and eppliention of escherotios. The tumour had been situated on the back of the sacrum and the coccyx; and when tho pationt

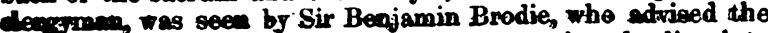
noo of the eloctrio centery, there wore two openings leading into m ivezalar covity, which from time to time gave exit to balls - to of hair. By introdacing a bundle of pery fine wires, and eanoing these to open apart by pressing their ends towands ane mother when in the sac, the interior was thoroughly doareged, and the oure completed Since that time, a similex cot upon the cheeik of a lady had been cured in the like mer. Fietnile in ano might also be divided by the incondescent wire, method that migbt be useful in a hrmarrbagio cenject; but the facility and safoty of the operation by the knife condered it mnecessary in ortinary cases. By means of the lowic centery, howevex, both imperfect and even. perfoet fistrilse in ano had been made to fill up and anite. In one ewe of each lind, the cure was permanent; in another oase of perfoet fisturles the truak of the wound again opened, whilst in throe the attempt at cure withent division failed. Of urinary fistules, ilr Marshall had cured one, and had another case, one of the most formidatle kind, under treatment, with every proppect of cone. In ceses of vesico-veginial fistule, the electric cautery peered very superior to my ather mode. Mr. Marshall defolod a ease in which a large commanication between the bladcar and vegina, edmitting three fingers, was completely closed by anoessive applientions of the cartery, slthough the cure was deleyed by the occurrenice of typhus in the patient. Amother ouse, - moler treatment, promised to be equally succestiful. Perseverance is necessary to the oure of these cases, but no peodiar precamtions seemed to be neoded. The cure alludod to was acom. plished without any confinement of the patient, except in the contior stages of the treatment. Of instences in which the

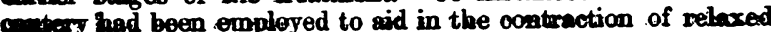
pasenges, the accident of prolapsus nteri, complicated with decoent of pert of the bladder, and rectum also, furrished the coly examples, in thereo out of four with good reswlts.

\section{ASSOCLATION INTELTGGNCE}

YOTLCE OF MOTION TO BE MADF AT TEE NFXT ANDUAL MEETING, FOR THE RHMOVAL OF THE TLME OF DR. WILLIAM O'CONNOR FROM THE IIST OF MEMBERS OF THE PROVINCIAL MEDICAI AMD SURGICAT, ASSOCIATION.

D. A. P. Stewart her addressed the following letter to the Secuetary of the Association; and has also sent a copy of it to Br. Winiem O'Combor.

74. Grosvenor Street, i0th July, 1851.

En -In acoontanoe with Law xall, I hereby give notice to rou of my intention to move the following resolation at the cheniversery Meeting of the Provinaial Medical and Surgieal

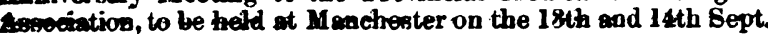

* Fhet Dr. William O'Connor having preferred against Dr. Conmek two speeifie eharges of falsehood, and having reiterated the same in a still more offensive form, after they had been cored on mimpenchable testimony to be groundless-thes chanfing by inplicetion several other members of the Aseccis. tion with wiffel falsehood-hes disquatified himself for the nembership of any body in which the common courtesies of Fise beild sacoed, and is hereby removed from the list of nombers of the Provineial Medical and Surgical Association."

I bave the homour to be, sir, your obedient servant,

Be.Tinarame, Woroester.

A. P. Strwart.

Enengur. In the list of new members in our loct number,

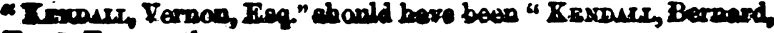
Fing", Temonith

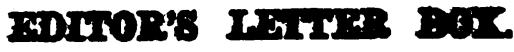 \\ THE ASSOCIATION-SHUTL IT BE CONALFED TO \\ THE PROVINCES? THE JOURNAT-SHAIT IT PE SUPERSEDED BY AN ANNDAT VOLJUM

$$
\text { OF TRANSACTIONS? }
$$

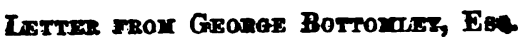

STR, - I wish to make a few observations upon that portion of the repert of the Metropolitan Counties Branch meeting of the 20th of Jume, relative to my claim of membership. [Vide pp. 421 and 557 .]

In No. 23 of the JouknaI of lest jear, dated the 10th of June, appears the following.

c Members of the Provincial Medical and Surgieal Ascocia tion, hsve the right of becoming members of the Motrapolitan

Counties Branch by simply paying the annual subscription of

28. 6d. to J. Toynbee, Esq. Treasurar, or T. Q. Ward, M.D. Secretery."

At the formation of the Metropolita Comnties Branch, I roceived a cireular inviting me to become a member of that Branch; it was my intention to accept the invitation, and a cam. weeks ago, I took the liberty of asking a member of the nonol. to pey the 2e.6d, and sead me the rooeipt: the 2s.6d. mas paid [12th June], and the receipt sent, and I considered mgelf a menen ber, and attended the meeting of the 13th of June, bnt we ne ported as being present as "A VIBTroR". On the following Tresday, the 20th of Juse, I attended the adjourned meeting, with the view of having what I believed to be an error rootifed, but the voice of the meeting was against my being oemoidered a member.

As a mamber of the Provineial Hedieal and Surgical Associe tion of some years standing, and also one of the Greneral Cona cil, I doem it my duty to offer a few remarks upon the present proceedings of the Metropolitan Counties Beanch.

The Metropolitan Counties Branch has made a bye-law for its own government, and aeted upon it-query, bas a Brach that power? I should say no; the Braneh, in my opiaion, should have first submitted sueh bye-lar to the Generad Council at the amual meeting, for the Council to determine whether sach bye-law chould be adoptod or rejected: malring such alterations in the bye-1ows, is, in my opinion, coutrory to all sale and order, and direotly opposed to the constitation of the Acoociotion.

Until the subject be fully discuseed by the Genemal Covenil at an annual meeting, I consider the lew for the odmiosien members to the Branch to be in foree, until resoinded by the Gemeral Council.

Why was the Provinciel Medical and Surgical Asseciation founded? I presume for the fellowing reasans, but pripeipaly in consequence of the very decided differenoe that exiods betwoen the provinaial and metropolitan practitioner: the prowinaia? practitioner is a one foosity practitioner, not so the mepalition: in the metropalis, the practice is divided into three guadeephysician, surgean, and apetheosry.

In the provimoes, the eurgeon is the physieian and phyeicianconchenr; in short, be takes the weighty reopemsitility of the whale upon himself, uot being oontent with performing the minor operations merely, as has been stated in the Colleos of Surgeans in London, which is more spolicable to the metro. politen practitioner; but be, the peovincial surgecen, perfocmen all the cepital operetions in surgery, not even declining the math cerions and difficult, sweh as amputation at the bip-joint, te.

The metropelitat prootitioner divide his reeponsibility with some consulting brother; not so the provibeisl, for a paw surgeon is a very scance person in the prowimces: thes, it ap pears, the interests of the two must be widely difecent, shiah difference bids fair to create a sobism in our ranks.

It will themefore beoome a question the next mnowl mot ing, whether the ones of the Ansocintion should not be confene. to the provinoes, and whether the metropolis shecild not itser toke charge of its own practitioners.

We of the country look forwerd to our anud meetingers well as the provincial Branch motings, with feelings of ploce sure and delight, where the grestest harmony and good foulinge have alwers prevailed; and we farventy bope thet so cocily of

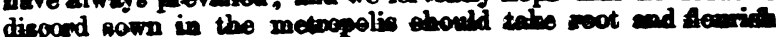
ancegost us.

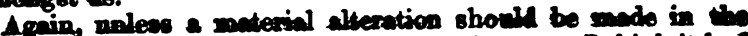

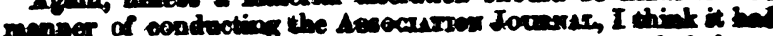

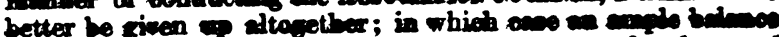

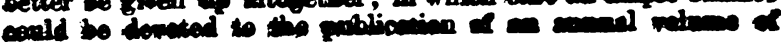

